\title{
The Implication of Flipped Learning Model in Tertiary Critical Reading Class
}

\author{
Yunani Atmanegara \\ Tridinanti University Palembang \\ yunaniatmanegara@univ-tridinanti.ac.id
}

Rahma Dianti

Tridinanti University Palembang

rahma_dianti@univ-tridinanti.ac.id

\begin{abstract}
This study investigated the implication of Flipped Learning Model toward tertiary students' critical reading skill. Classroom action research was carried out to conduct the study. Critical reading test, observation of students' learning participation outside and inside class, and interview were administered to gather the data. This study used descriptive analysis. Students' prior critical reading skill was considerably low. They did not have self-initiative to practice their reading skill. After implementing this model for three cycles, progress on their critical reading could be noticed. Flipped Learning Model could trigger students' learning participation both outside and inside classrooms. Yet, students still needed teacher's assistance to direct their learning process. Flipped model of instruction encouraged students to be able to analyze and evaluate the texts. However, students still had difficulty in internalizing the information to formulate ideas as creating skill needs more practice to achieve. Appropriate learning materials, students' awareness, and environmental supports influenced the implication of Flipped Learning Model implementation.
\end{abstract}

Keywords: Flipped learning model, critical reading skill, tertiary students

\section{INTRODUCTION}

Reading takes on a central role in higher education. Students have to read a large number of resources not only books but also journal articles and academic papers to support their academic performance. Academic reading is a mandatory activity for tertiary students to 
achieve academic success. According to Hermida (2009), reading is one of fundamental academic skills at university level as well as writing, critical thinking, oral presentation, and media literacy. Nowadays, abundant yet complex reading passages can be easily accessed. Moreover, technology innovation provides many conveniences in accessing various reading sources. ICT as a new literacy now make students access reading sources easily (Apriani, 2016). Using ICT in learning process can motivate (Apriani, 2019), attract, and enhance the success of learners in studying English skill (Apriani, 2019). Therefore, students have to critically read passages to obtain relevant information according to their needs.

Cultivating tertiary students' critical reading skill is very beneficial since this skill allows students to gain comprehensive understanding of written materials which will eventually help them analyze -strong evidence and well-reasoned argument provided in the texts. Critical reading also emerges as developing behavior at the

level of analysis, evaluation, and creation. Readers apply their critical thinking in reading activity as they need to analyze, question, judge, and evaluate information obtained from texts (Karaca \& Ogus, 2017; Pardede, 2007; Pirozzi 2003). In addition, critical readers use their cognitive competence and critical attitudes of reading such as careful, active, reflective, and analytic during reading process (Asilioglu, 2008; Kurland, 2000). They not only passively absorb all the information from the texts but also appropriately decide what to accept and believe.

To grasp the sense of the text, critical reading activity involves Higher Order Thinking Skills (HOTS) that comprises three highest levels of thinking skills namely analyzing, evaluating, and creating. Those skills enable students to selectively use the information from a lot of choices of sources. Therefore, in this information and technological innovation era, critical reading ability becomes the foundational skill in high levels of education (Ndethiu, 2017; Kress, 2003; Walz, 2001). Furthermore, integrating HOTS into learning process helps students improve their critical thinking skill. Reinforcing students' critical thinking skill can give powerful effect on students' success in learning. It is consistent with the education policy of Indonesian government (2018) that requires 
teachers to incorporate HOTS into their teaching practice to direct students to be able to think critically and creatively. HOTS oriented learning can improve the quality of smart and successful students.

According to Schleicher (2019), students are supposed to be able to read complex texts, select credible and valid sources of information, and update the accepted knowledge and practices. Nevertheless, the latest survey of PISA 2018 revealed that students still encountered problems in reading even for the most basic reading tasks. The results of PISA 2018 showed that Indonesia ranked 74 out of 79 countries in terms of reading skill. It indicated that Indonesian students' reading skill is still very poor. Zin and Eng (2014) added that Asian students are categorized as non-critical readers and thinkers. Different culture, language background, and learning styles might cause different critical reading abilities in tackling the texts while reading. Apriani (2016) in her study also found that students' in junior high school had problems in reading. Meanwhile, Muhlis (2017) confirms that most of senior high school students perceived medium level of foreign language reading anxiety. As the result, most university students were not prepared for academic setting environment that insists them to be critical in reading the texts, therefore they adopt a superficial approach in reading academic materials.

Some possible factors that could contribute to the students' low skill in critical reading were teachers rarely stimulated students with high order level of questions (Sunggingwati \& Nguyen, 2013), students lacked ability to apply analytical and inferential skills because of the low English language proficiency (Zin, Eng \& Rafik-Galea, 2014), and students had low comprehension skill to infer the implicit argument and analyze the text tone (Par, 2018; Attaprecakul, 2013). Furthermore, Alghail and Mahfoods (2016) found five academic reading difficulties faced by university students consisting of internalizing relevant information, summarizing the information using their owns' words, decoding unfamiliar words, finding out supporting ideas and evidence, and managing the time for completing reading academic materials.

In light of those problems, it is vital for the teachers to employ effective teaching variety that stimulates students' critical reading skill. 
Inderawati, Sofendi, Purnomo, Vianty, and Suhendi (2019) claim that technology brings change in teaching and learning practice to be more effective and efficient. Moreover, students need to develop their ICT skills and collaborative learning to respond to the challenges of Education 4.0. Flipped learning model triggers students' learning desire to integrate technology tools into their reading activities. It is one of the models in blended learning since it combines both face-to-face learning and online learning to facilitate teaching and learning process. Flipped learning model offers students more opportunities to have self-paced learning. This model encourages students to learn theoretical parts outside the classroom, whereas the practical parts are taught face to face and interactively (Chea \& Huan, 2019).

Flipped classroom positively affected students' critical thinking (Asmara, Kusumaningrum, Wulansari, Munirah, \& Hersulastuti, 2019; DeRuisseau, 2016). Furthermore, students' higher order thinking skill, engagement, and satisfaction could be improved due to flipped model of instruction (Alsowat, 2016). This learning model promotes students' learning engagement through collaborative activity, peer discussion, and problem-based learning. Students are encouraged to take control of their own learning and develop their critical thinking towards its implementation. Sharples, Adam, Verguson, Gaved, McAndrew, Rientites, Weller, and Whitelock (2014) confirmed that flipped learning is an innovative pedagogical approach conveying high potential impact for higher education students.

In reading class, Karimi and Hamzavi (2017) affirmed that flipped learning model had a significant positive effect on EFL students' reading comprehension development. A number of students became more confident and independent to learn in class since they had brainstormed the background knowledge or ideas at their own pace. Lu (2016) added that implementing flipped classroom in English reading course gives opportunities for students to use various reading styles, access rich reading content, and get better comprehension. Meanwhile, Al-Rowais (2014) affirmed that flipped learning model could improve students' academic achievement and their learning attitudes. This model also builds peer interaction and collaboration in class session. 
The above elaboration shows that Flipped Learning Model can be a potential and beneficial choice to accommodate students' critical reading practices since this model provides the students with two different learning modes, inside and outside the classroom. Most of previous studies on reading skill cultivation only focused on exploring teaching varieties that gave deep exposure on reading practices through classroom instruction. Very few studies had undertaken on exploring reading practice both inside and outside the classroom. Meanwhile, practicing students to read critically for both inside and outside classroom instruction is really on demand especially for tertiary level. Higher education requires students to be more responsible to take their own control during reading activities outside the classroom. They are supposed to have independence and self-initiative to read on their own. However, most students of English education study program at Tridinanti University only performed reading practices when they participated in reading class. They had no self-initiative to do reading activities outside the class. As response to this condition, this study attempted to conduct a classroom action research focusing on investigating the implication of Flipped Learning Model in empowering tertiary students' critical reading skill.

\section{THEORETICAL FRAMEWORK \\ Critical Reading Skill in Tertiary Level}

Developing tertiary students' critical reading skill is very important to lead them to get appropriate information according to their needs and discover meaning beyond the text. Hudson (2007) defines critical reading skill as the skill that will help students to be able to analyze, synthesize, and evaluate what is read. The aim of critical reading is to assess whether the passage supported by strong evidence and a well-reasoned argument. Students may not only passively agree with everything they read in an academic context but also compare, contrast, find fault with, agree, disagree, question and evaluate each and every text (University of Technology Sydney, 2017). 
Furthermore, Students Learning Development University of Leicester (2009) mention the characteristic features of critical reading as follows:

1. examine the evidence or arguments presented

2. check out any influences on the evidence or arguments

3. check out the limitations of study design or focus

4. examine the interpretations made

5. decide to what extent readers are prepared to accept the authors' arguments, opinions, or conclusions.

\section{Flipped Learning Model}

Flipped learning model was developed in the 1990s. This model helps students to prepare and reflect on the learning materials before class and then use peer interaction during class time to encourage deeper understanding about the subject matters (Crouch \& Mazur, 2001). Flipped learning came into general use in the early mid-2000s and use technology tools to deliver materials to students before class. Flipped Learning Network (2014) coins four pillars from the word "FLIP" as the framework of this model:

1. Flexible Environment - students choose when and where they learn

2. Learning Culture -the learning mode is shifted into a learnercentered approach, the topic is explored in greater depth in class.

3. Intentional Content -teachers determine what to teach and what materials students should explore on their own

4. Professional Educator - teacher serves as facilitator to enable Flipped Learning to occur.

Bishop and Verleger (2013) point out two essentials learning sessions of Flipped Learning Model: out-of-class and in-class sessions. Students learn out-of-class to acquire the knowledge through educational technology while learning in-class session is conducted through interaction with peers and teachers. Edmodo can be used as the online learning platform to mediate students' learning in out-of-class session. Compared to others' learning platforms, Edmodo deploys many advantages. It provides a simple way for teachers to create and manage an online classroom community as well as enables students to connect and work with their classmates and teachers anywhere and anytime (Balasubramaniana, Jaykumar \& Fukey, 2014). 


\section{RESEARCH METHODOLOGY}

Research Design

Research design administered in this study was classroom action research (CAR). Stringer (2007) states that action research investigates a systematic approach to get effective solutions for the problems. This study aimed at investigating Flipped Learning Model implementation in empowering students' critical reading skill. This CAR was carried out in four stages: planning, action, observation, and reflection. It was conducted in 3 cycles (March 3 - May 31, 2019) consisting of four meetings in each cycle. Researcher 1 served as lecturer while researcher 2 served as observer.

Population and Sample

The population of this study was the students of English education study program at Tridinanti University Palembang. In selecting the sample, purposive sampling technique was administered. 16 students who were taking critical reading course participated in this study. The students had taken the prerequisite reading courses including basic, literal, and interpretative reading courses.

Data Collection

The data were collected by using test, observation, and interview. The test was administered to collect the data about students' critical reading skill before and after the action stage. The researchers observed the learning process both in-class and out-of-class by using observation sheet. Interview was administered to get supplementary data to strengthen the observations results of this study.

Data Analysis

The data of critical reading test were calculated and analyzed by using percentage analysis. The improvement of students' critical reading skill was shown by the increasing of percentage from the learning completeness and critical reading aspects (analyzing, evaluating, and creating). The standard of learning completeness used Tridinanti University score standard ( $\geq 70$ ) with the indicator of learning success was $\geq 85 \%$. Mean scores of pre-cycle test, progress test 1,2 , and 3 were 
compared to see the progress achieved by students in every cycle. Meanwhile, the data from in-class and out-of-class observations were served in the form of diagram and descriptively analyzed. Moreover, the interview results were used to support the description of observation.

\section{FINDINGS AND DISCUSSION}

\section{Findings}

The Result of Preliminary Studies

The researchers did some preliminary studies to identify the students' prior reading skill. The researchers investigated students' reading achievement in the third semester for interpretive reading course since it was the prerequisite course to take critical reading subject. The mean score of students' interpretive reading was 64.14. It indicated that students reading ability was still below the standard. Furthermore, researchers interviewed interpretive reading lecturer to know what problems encountered by lecturer and students during interpretive reading class. The lecturer reported some obstacles during teaching because students lacked decoding vocabulary skill. In addition, most students got difficulties in finding main ideas and making inferences of English reading texts. Students could not read beyond the text and still comprehended the text literally. Meanwhile, students did not have initiative to read on their own. They still needed lecturer's assistant to practice their reading both inside and outside classroom. This condition showed that they were not active and independent in learning especially in reading. They did not realize that they were required to have independence in academic reading in higher education.

\section{Results of Critical Reading Test}

Pre-Cycle Test

At the beginning of the study, pre cycle test was given to the students to measure their critical reading skill before implementing Flipped Learning Model. The results of pre cycle test showed that no student could reach the standard score (70) while the maximum score was 64 , the minimum score was 24 , and the mean score was 41.5 . 
Furthermore, the results of critical reading sub-skills showed that students could answer $43.3 \%$ for analyzing, $47.9 \%$ for evaluating, and $31.3 \%$ for creating.

Progress Test 1

After implementing Flipped Learning Model in cycle 1, progress test 1 was given to the students to evaluate their critical reading skill progress. The result showed that learning completeness achieved $31.25 \%$ while the maximum score was 76 , the minimum score was 32 , and the mean score was 55.5. In addition, the results of critical reading sub-skills showed that students could answer $54.8 \%$ for analyzing, $67.7 \%$ for evaluating, and $44.8 \%$ for creating. Mean difference between pre cycle test and progress test 1 was 14 . It indicated that there was slightly improvement on students' critical reading skill. Since the results were still below the standard score and success indicator, the study was continued to cycle 2 .

Progress Test 2

At the end of cycle 2, progress test 2 was given to the students. It was found that learning completeness achieved $62.5 \%$ while the maximum score was 80 , the minimum score was 45 , and the mean score was 66.56. Moreover, the results of critical reading sub-skills showed that students could answer $70.2 \%$ for analyzing, $69.8 \%$ for evaluating, and $55.2 \%$ for creating. Mean difference between progress test 1 and progress test 2 was 11.06. It indicated that the improvement of students' critical reading skill did not exceed the success indicator. Therefore, cycle 3 would be conducted.

Progress Test 3

After administering progress test 3, it was found that $87.5 \%$ of the students achieved the learning completeness while the maximum score was 88 , the minimum score was 61 , and the mean score was 76.31 . Mean difference between progress test 2 and progress test 3 was 9.75. Meanwhile, the results of critical reading sub-skills showed that students could answer $81.3 \%$ for analyzing, $77.1 \%$ for evaluating, and $64.6 \%$ for creating. The results exceeded the standard score and success indicator. In other words, the results had reached the target. It means 
that Flipped Learning Model could empower tertiary students' critical reading skill. The summary of critical reading test results is presented in Table 1.

Table 1.

The Summary of Critical Reading Test Results

\begin{tabular}{lcccc}
\hline & $\begin{array}{c}\text { Pre-Cycle } \\
\text { Test }\end{array}$ & $\begin{array}{c}\text { Progress } \\
\text { Test 1 }\end{array}$ & $\begin{array}{c}\text { Progress } \\
\text { Test 2 }\end{array}$ & $\begin{array}{c}\text { Progress } \\
\text { Test 3 }\end{array}$ \\
\hline $\begin{array}{l}\text { Learning } \\
\text { Completeness }\end{array}$ & $0 \%$ & $31.25 \%$ & $62.5 \%$ & $87.5 \%$ \\
\hline Mean & 41.5 & 55.5 & 66.56 & 76.31 \\
\hline Maximum & 64 & 76 & 80 & 88 \\
\hline Minimum & 24 & 32 & 45 & 61 \\
\hline Analyzing & $43.3 \%$ & $54.8 \%$ & $70.2 \%$ & $81.3 \%$ \\
\hline Evaluating & $47.9 \%$ & $67.7 \%$ & $69.8 \%$ & $77.1 \%$ \\
\hline Creating & $31.3 \%$ & $44.8 \%$ & $55.2 \%$ & $64.6 \%$ \\
\hline
\end{tabular}

\section{Observation Results}

Out-of-Class Observation

This observation was conducted in every meeting to observe students' learning participation outside the classroom. Students were given one week to complete the worksheet and submit it back to Edmodo. The results of observation revealed that $81.3 \%$ of the participants could complete the assignment before the due time, $6.3 \%$ exceeded the due time, and $6.3 \%$ undefined. It indicated that the implementation of Flipped Learning Model could encourage the participants to be more responsible in managing their time in submitting the worksheet. In completing the worksheet, most of students used internet connection to find supporting learning resources from various websites or journals, YouTube, Wikipedia, Encyclopedia, and electronic books. They used their own initiative to complete this. In addition, content became the hardest aspect to achieve. Regarding to the content of the students' answers, they gave less valid answers since they mostly used only one relevant and scientific resource to support their answer. 
In-Class Observation

Classroom observation was administered at the end of each cycle. Three aspects were observed during the implementation of Flipped Learning model: students' learning performance, participation, and behavior.

a. Learning Participation

In cycle 1 , students did not participate actively during in-class session. Most of students (87.5\%) still needed lecturer's assistance to complete the reading assignments during in-class session. $68.75 \%$ of the students did not actively participate during class discussion, did not ask questions, did not answer the questions voluntarily, and did not have self-initiative in working with the tasks. Only $43.75 \%$ of the students did the work thoroughly and interacted academically with their peers.

In cycle 2, they showed better learning participation during inclass session. Most of the students (87.5\%) followed the lecturer's direction well. $81.25 \%$ of the students academically interacted with their peers. $75 \%$ of the students did the work thoroughly and participated actively in class discussion. They also started to ask and answer questions voluntarily. However, students still needed teacher's assistance and did not have self-initiative in working with the tasks.

In cycle 3 , students' learning participation significantly improved. Most students (93.75\%) actively participated and interacted with their peers in class discussion. $87.5 \%$ of the students voluntarily answer the questions and did the works thoroughly. They also built their selfinitiative in working with the tasks and in answering the questions. Unfortunately, $50 \%$ of the students still depended on teacher's assistance during learning process. Figure 1 depicts the result of in-class observation for learning participation. 


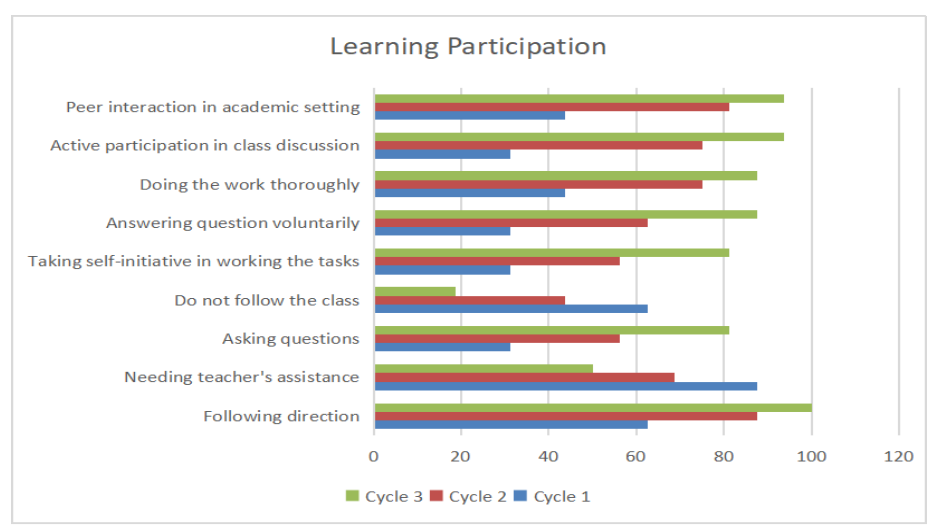

\section{Figure 1. Observation Result of Learning Participation}

Based on the results above, it could be said that Flipped learning model implementation could significantly increase students' learning participation. Students actively participated during learning process in each class session. They could interact with peers in academic setting. However, they still needed lecturer's assistance to direct them in doing peer discussion.

\section{b. Learning Performance}

There were 10 indicators observed related to students' learning performance during Flipped Learning model implementation. In cycle 1, the students showed slow progress in their learning performance. Based on the observation results, it indicated that mostly students (87.5\%) still got problems in creating and summarizing their own ideas. They (75\%) could not find strong evidences to support their ideas or answers during class discussion and completed the given tasks. $68.75 \%$ did not have good decision-making skill, could not express ideas clearly, and did not consider others' suggestions. $50 \%$ of the students could finish and willingly work with reading assignment sincerely.

The observation results in cycle 2 revealed that creating and summarizing skills still remained the problems. Only $37.5 \%$ of the students could create and summarize the ideas. In addition, $50 \%$ of the students still had problems in their self-motivation, decision making skill, and finding appropriate evidences to support their ideas or answers. $68,8 \%$ of the students could consider others' suggestion, work 
willingly, and finish assignment with sincere effort.

In cycle 3, students showed significant progress in their learning performance during the implementation of Flipped learning model. Unfortunately, the aspects of creating and summarizing and decisionmaking skills remain the problems. Only $62.5 \%$ of the students could create and summarize their ideas, and make good decision in completing the reading tasks. Figure 2 portrays the observation results of in-class session for learning performance.

The results show that the implementation of Flipped Learning Model could help students perform better in their reading practice. They were able to finish the assignment with sincere effort and could provide ideas with evidence. Yet, they still got difficulty in creating and summarizing ideas in their own words.

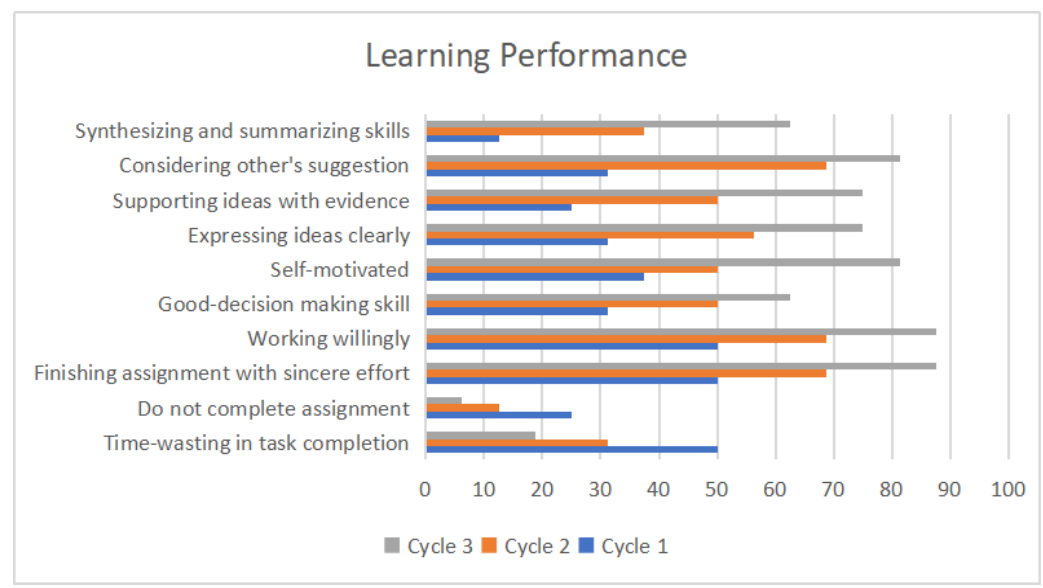

Figure 2. Observation Result of Learning Performance

c. Learning Behavior

There were 6 indicators observed for learning behavior aspect. During the implementation of Flipped Learning model in cycle 1, the students still had problems in their learning behavior. All of the students could not work individually to complete the tasks. Most of the students (69.75\%) were also easily distracted in completing the reading tasks and not confident to report their work to the whole class. Meanwhile, $62.5 \%$ of the students did not show integrity during learning process. $56.25 \%$ of the students did not try to complete the reading tasks 
sincerely and were not responsible in their learning activities during inclass session. In cycle 2, students' learning behavior slightly increased. Most of the students (75\%) showed high responsibility toward their learning activities. They (68.75) also showed integrity during learning process. $62.5 \%$ of the students were confident enough to report their work during class discussion and tried to complete the reading tasks with sincere effort. However, students still easily got distracted in completing the tasks. In cycle 3, students showed significant improvement in their learning behavior. Most of students (87.5\%) consistently did the reading tasks on their own, tried to complete the reading tasks with sincere effort, showed integrity during the learning process, and significantly built their responsibility toward their own learning. Unfortunately, ICT usage during the learning process still remained the problems. It became distraction for them when completing the tasks. Figure 3 portrays the observation result of learning behavior during the implementation of Flipped Learning model.

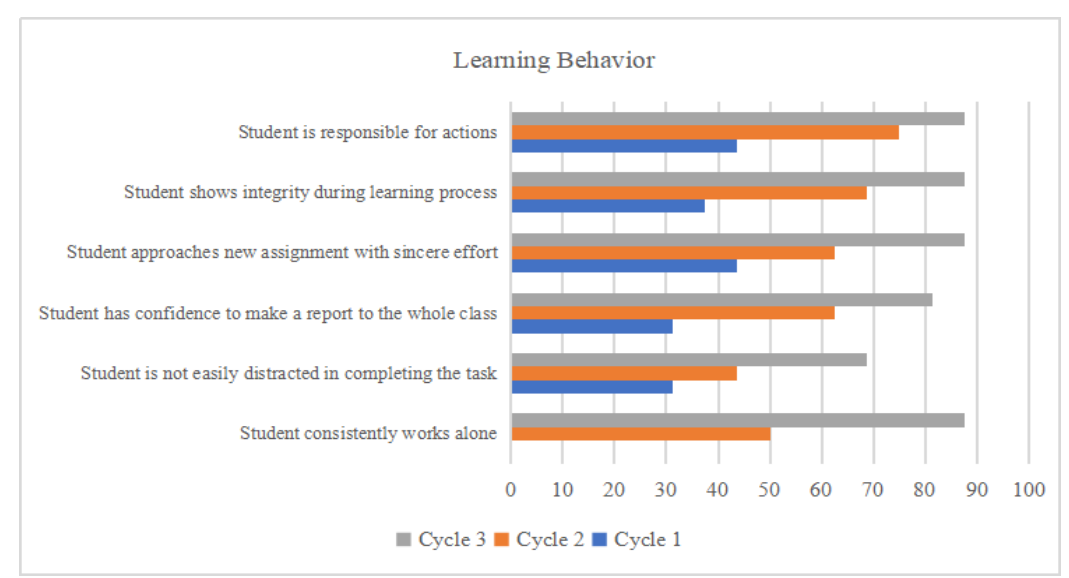

Figure 3. Observation Result of Learning Behavior

Based on those findings, it indicated that the implementation of Flipped learning model could encourage the students to be more responsible toward their own learning and build their self-confidence to deliver their work report to the whole class. However, they were easily distracted due to the use of ICT devices during the learning process. 


\section{Interview Results}

The results of interview revealed that all students agreed they could use their learning time efficiently during flipped learning model implementation. In selecting the learning resources, $62.5 \%$ of the students could find appropriate materials. For the students' learning participation out of class, $100 \%$ of the students completed the worksheet on their own initiative while $93.8 \%$ of the students actively participated during in-class discussion. Moreover, students were able to analyze and evaluate the texts even though they struggled to grasp the meaning. Finally, students could build their self-initiative to reflect their ideas and thoughts in implementing Flipped Learning Model.

\section{Discussion}

After implementing Flipped Learning Model for three cycles on students' critical reading class, some points could be discussed. Flipped Learning Model could empower tertiary students' critical reading skill. The final results had exceeded the success indicator of this study. Two learning sessions of this model helped the students to understand more on the topic discussed. Karimi and Hamzavi (2017) confirm that students reading performance was better because of the flipped model of instruction. Before implementing Flipped Learning Model, students did not have self-initiative to practice their reading skill. The implementation of this model helped students manage their learning time to have more reading practice. This model could stimulate their independence to find various supporting learning sources to complete the reading worksheet. However, students could not provide rich content for the worksheet. They still lacked decision making skill to create and summarize the ideas. Students got difficulty in internalizing the information to create their own ideas.

In class learning session, the implementation of this model could encourage students' learning participation. At the beginning of the study, students did not actively participate during class discussion. Most of the students relied on the teachers' assistance to participate in learning process. Flipped Learning Model could increase students' learning participation and motivate them to be critical in responding to 
the text. They analyzed, questioned, judged, and evaluated the information obtained from texts. Therefore, students could engage in peer discussion and were able to interact with peers in academic setting even tough teacher's role is still needed to direct them in doing peer discussion. This model also encouraged students' active participation in collaborative learning. Wu, Chen, and Yang (2017) confirm that Flipped Classroom could develop peer interaction and collaboration. Furthermore, Flipped Learning Model could help students to perform better in analyzing and evaluating skill. During the in-class learning session, students could read the text more profoundly since they already constructed the knowledge about the topic discussed. They could give supporting ideas with evidence. Hence, the implementation of this model could help them decide appropriate, credible, and valid information from the texts as critical readers used their cognitive competence and critical attitudes during their reading process (Asilioglu, 2008; Kurland 2000). Nevertheless, creating skill remains the problem faced by the students. It might be caused by the students' tendency to rely on the teacher's confirmation in generating ideas since they were not confident enough to create new ideas. This condition might also be influenced by students' reading comprehension. They still struggled to grasp the meaning beyond the text. Consequently, lecturer spent more time to practice analyzing and evaluating skill rather than the creating skill during the implementation of Flipped Learning Model.

At last, the implementation of flipped learning model triggered students' learning engagement. Students showed positive learning attitude during the implementation of this model. It is in line with AlRowais (2014) that flipped learning model can enhance students' academic achievement and affect positive attitudes toward the learning course. Meanwhile, students could comprehend the text better and involved their higher critical thinking skill during its implementation. It is consistent with $\mathrm{Lu}$ (2016) that implementing Flipped classroom in English reading class allowed students to use various reading style to access rich reading content. However, the use of ICT devices during its implementation should be considered since students were easily distracted by the use of technology in completing the task. 


\section{CONCLUSION}

The implementation of Flipped Learning Model could empower tertiary students' critical reading skill. This model could promote students learning engagement since it contains two learning sessions; out of class and in-class session. Out of class activity helped students build background knowledge so that they could link the information to the topic discussed. This activity directed them to have deeper understanding in reading the text. Therefore, students were able to analyze and evaluate the texts. However, they still need more reading practice to develop their creating skill.

\section{REFERENCES}

Alghail, A. A. A. \& Mahfoodh, O. H. A. (2016). Academic reading difficulties encountered by international graduate students in a Malaysian university. Issues in Educational Research, 26(3), 369-386.

Al-Rowais, A. S. (2014). The impact of flipped learning model on achievement and attitudes in higher education. International Journal for Cross-Disciplinary Subjects in Education, 4(1), 1914-1921.

Alsowat, H. (2016) An EFL flipped classroom teaching model: Effects on English language higher-order thinking skills, student engagement, and satisfaction. Journal of Education and Practice, 7(9), 108-121.

Apriani, E. (2016). A New Literacy: The Role of Technology to Develop Student's Character. Ta'dib:Journal of Islamic Education (Jurnal $\begin{array}{lllll}\text { Pendidikan } & \text { Islam), 21(1), } & 59 & - & 72 .\end{array}$ https://doi.org/https://doi.org/10.19109/tjie.v21i1.742.

Apriani, E. (2016). Using The Think-Pair-Share (TPS) Strategy to Enhance Students' Reading Achievement of The Seventh Grade at MTsN Lumpatan. Belajea; Jurnal Pendidikan Islam, 1(2). doi:http://dx.doi.org/10.29240/bjpi.v1i2.110.

Apriani, E., Supardan, D., Sartika, E., Suparjo, S., \& Hakim, I. N. (2019). UTILIZING ICT TO DEVELOP STUDENT'S LANGUAGE ETHIC AT ISLAMIC UNIVERSITY. POTENSIA: Jurnal Kependidikan Islam, 5(1), 114. 
Apriani, E., \& Hidayah, J. (2019). The ICT Used by the English Lecturers for Non-English Study Program Students at IAIN Curup.Vision: Journal for Language and Foreign Language Learning, 8(1), 26-37.

Asilioglu, B. (2008). Importance and means of critical reading for cognitive learning. Journal of D.U Ziya Gokalp Faculty of Education,10 11.

Asmara, R., Kusumaningrum, W. R., Wulansari, A., Munirah. \& Hersulastuti. (2019). Measuring the effect of flipped classroom model on critical thinking skills. 2nd Workshop on Language, Literature and Society for Education. Retrieved from http://dx.doi.org/10.4108/ eai.21-12-2018.2282743

Attaprechakul, D. (2013). Inference strategies to improve reading comprehension of challenging texts. English Language Teaching, 6(3), 82-91.

Balasubramaniana, K, Jaykumar, V. \& Fukey, L. N. (2014). A study on "student preference toward the use of Edmodo as a learning platform to create responsible learning environment". Procedia - Social and Behavioral Sciences, 144, 416-422.

Bishop, J. L. \& Verleger, M. A. (2013). The flipped classroom: A survey of the research. 120th American Society for Engineering Education Conference Annual Conference and Exposition, 30, 1-18.

Chea, C. C. \& Huan, J. T. J. (2019). Higher education 4.0: The possibilities and challenges. Journal of Social Science and Humanities, 5(2), 81-85.

Crouch, C. H. \& Mazur, E. (2001). Peer instruction: Ten years of experience and results. American Journal of Physics, 69(9), 970-977.

DeRuisseau, L. R. (2016). The flipped classroom allows for more class time devoted to critical thinking. Advances in Physiology Education, 40(4), 522-528.

Flipped Learning Network. (2014). What is flipped learning? Retrieved from https://flippedlearning.org/wp-content/uploads/2016/07/ FLIP handout_FNL_Web.pdf

Hermida, J. (2009). The importance of teaching academic reading skills in first-year university courses. The International Journal of Research 
and Review, 3, 20-30.

Hudson, T. (2007). Teaching second language reading. Oxford: Oxford University Press.

Inderawati, R., Sofendi, Purnomo, M.E., Vianty, M. \& Suhendi, D. (2019). Students' engagement in utilizing technology for learning support. English Franca: Academic Journal of English Language and Education, 3(2). 181-196.

Karaca, P. O. \& Ogus, F. G. (2017). A conceptual evaluation on critical reading. IOSR Journal of Humanities and Social Science (IOSR-JHSS), 22(12), 38-41. doi: 10.9790/0837-2212073841

Karimi, M. \& Hamzavi, R. (2017). The effect of flipped model of instruction on EFL learners' reading comprehension: Learners' attitudes in focus. Advances in Language and Literary Studies, 8(1), 95-103.

Kress, G. (2003). Literacy in the new media age. London: Routledge.

Kurland, D. J. (2000). Critical reading vs critical thinking. Retrieved from http://www.criticalreading.com

Lu, S. (2016). A tentative research on the college English reading teaching mode based on the theory of the flipped classroom. 5th International Conference on Social Science, Education, and Humanities Research (SSEHR). 1660-1663.

Ministry of Education and Culture. (2018). Mendikbud imbau guru terus kembangkan model pembelajaran HOTS. Retrieved from https://www.kemdikbud.go.id/.

Muhlis, A. (2017). Foreign language reading anxiety among Indonesian EFL senior high school students. English Franca: Academic Journal of English Language and Education, 1(1), 19-44.

Ndethiu, S. M. (2017). Critical reading skills for the 21st century: The role of universities. IOSR Journal of Humanities and Social Science (IOSR-JHSS), 22(12), 53-59. doi: 10.9790/0837-2212055359

Par, L. (2018). The EFL students' critical reading skills across cognitive styles. Journal of English Education and Linguistics Studies, 5(1), 7396. 
Pardede, P. (2007). Developing critical reading in EFL classroom. FKIPUKI English Department Bimonthly Collegiate Forum, 1(1), 1-16.

Pirozzi, R. (2003). Critical reading, critical thinking (2nd ed.). New York. Longman.

Schleischer, A. (2019). PISA 2018: Insights and interpretations. Paris: OECD Publishing.

Sharples, M., Adams, A., Ferguson, R., Gaved, M., McAndrew, P., Rienties, B., Weller, M. \& Whitelock, D. (2014). Innovating pedagogy 2014: Open university innovation report 3. Retrieved from http://www. openuniversity.edu/sites/www.openuniversity.edu/files

Stringer, E.T. (2007). Action research (3rd ed). California: Sage Publications Inc.

Students Learning Development University of Leicester. (2009). What is critical reading? Retrieved from https://www2.le.ac.uk/offices/ld/ resources/studyguides-pdfs/writing-skills-pdfs/critical-readingv1\%200.pdf

Sunggingwati, D. \& Nguyen, H. T. M. (2013). Teachers' questioning in reading lessons: A case study in Indonesia. Electronic Journal of Foreign Language Teaching, 10(1), 80-95.

University Technology of Sydney. (2017). Critical reading. Retrieved from https://www.uts.edu.au/current-students/support/helps/self-help resources /reading/critical-reading

Walz, J. (2001). Critical reading and the internet. The French Review, 74(6), 1193-1205.

Wu, W. C. V., Chen, H, J. S. \& Yang J. C. (2017). Creating an online learning community in a flipped classroom to enhance EFL learners' oral proficiency. Educational Technology \& Society, 20(2), 142-157.

Zin, Z. M. \& Eng, W. B. (2014). Relationship between critical thinking dispositions and critical reading skills of Malaysian ESL learners. The Asian EFL Journal Quarterly, 16(3), 41-68.

Zin, Z. M., Eng, B. E. \& Rafik-Galea, S. (2014). Critical reading ability and its relation to L2 proficiency of Malaysian ESL learners. The Southeast Asian Journal of English Language Studies, 20(2), 43-54. 